\title{
Dosering av digitoksin i klinisk praksis
}

\author{
Sammendrag \\ Bakgrunn. I 2007 kom det anbefalinger \\ om at serumkonsentrasjonen av digi- \\ toksin bør ligge i området 8-15 nmol/l, \\ noe som er ca. halvparten av det som \\ tidligere var ansett som optimalt, og \\ forslag til nye doseringsrutiner.
}

Materiale og metode. Utviklingen for angitt dosering og serumkonsentrasjoner av digitoksin er undersøkt med utgangspunkt i 13054 prøver sendt til Avdeling for klinisk farmakologi ved St. Olavs hospital for analyse fra 1.1. 2000 til 31.12. 2008.

Resultater. Mediankonsentrasjonen av digitoksin lå stabilt på ca. $25 \mathrm{nmol} / \mathrm{l}$ til og med 2006. Fra 2007 sank mediankonsentrasjonen gradvis og var 19 $\mathrm{nmol} / \mathrm{l}$ ved utgangen av 2008. Serumkonsentrasjonen $\mathrm{i}$ to tredeler av prøvene var da høyere enn det nye referanseområdet. Gjennomsnittlig døgndose sank fra $66 \mu \mathrm{g}$ til $56 \mu \mathrm{g}$ i løpet av perioden. Personer over 85 år hadde nesten dobbelt så høye konsentrasjoner på en gitt dose som individer under 55 år.

Fortolkning. Serumkonsentrasjonene av digitoksin har gradvis gått ned etter 2007, men er ofte høyere enn det nye referanseområdet. For å unngå for høye serumkonsentrasjoner må doseringen være lik eller lavere enn nå anbefalt, særlig hos de eldste pasientene.

\section{Arne Hønnås}

arne.honnas@stolav.no

Avdeling for klinisk farmakologi

St. Olavs hospital

7006 Trondheim

\section{Arne Reimers}

Olav Spigset

Avdeling for klinisk farmakologi

St. Olavs hospital

og

Norges teknisk-naturvitenskapelige universitet

I 2007 ble det i nye norske anbefalinger pekt på at doseringen av digitalispreparater bør være lavere enn det som tidligere ble ansett som riktig (1-3). Det ble også foreslått endringer i doseringsrutinene (3), med vedlikeholdsdosering på 30-50 $\mu$ g daglig, og eventuelt med 1-2 doseringsfrie dager i uken. Anbefalingene var basert på data som tilsa at serumkonsentrasjonen ved behandling av hjertesvikt bør være $8-15 \mathrm{nmol} / 1$ for digitoksin og $0,6-1,2 \mathrm{nmol} / 1$ for digoksin $(2,3)$. Dette er rundt regnet en halvering i forhold til det som tidligere var ansett som optimalt (4). De nye tallene var basert på en stor observasjonsstudie (5), der tilleggsanalyser viste at mortaliteten ved hjertesvikt var høyere når serumkonsentrasjonen av digoksin var over $1,2 \mathrm{nmol} / 1(6,7)$.

Dataene som lå til grunn for endringen i referanseområdet har noen begrensninger. For det første var kun digoksin studert, og ikke digitoksin, som er det mest brukte digitalisglykosidet i Norge. Det er knyttet en viss usikkerhet til hva som er det tilsvarende optimale referanseområdet for digitoksin. For det andre var pasientene ikke randomisert til de ulike plasmakonsentrasjonene. Det kan derfor være ukjente bakenforliggende faktorer som medfører at pasienter med de høyeste plasmakonsentrasjonene kom dårligst ut. For det tredje var det kun pasienter med hjertesvikt som ble studert, og det er usikkert om referansenivåene bør være de samme for pasienter med atrieflimmer.

To studier fra 1970-årene er de eneste der man relativt detaljert har sett nærmere på forholdet mellom digitaliskonsentrasjon og hjertefrekvens hos pasienter med atrieflimmer $(8,9)$. I begge studiene ble det brukt digoksin. I den første studien fant man at pasienter med en hjertefrekvens på 61-80 slag per minutt $\mathrm{i}$ gjennomsnitt hadde en konsentrasjon på 2,6 nmol/1, de med en frekvens på 81-100 hadde en konsentrasjon på
1,9 nmol/1, mens de med en frekvens på over 100 hadde en konsentrasjon på $1,3 \mathrm{nmol} / 1$ (8). Dette tilsvarer digitoksinkonsentrasjoner på rundt regnet henholdsvis $32,24 \mathrm{og}$ $16 \mathrm{nmol} / 1$, altså svært høyt i forhold til de nye anbefalingene. I den andre studien fant man ingen sammenheng mellom plasmakonsentrasjon og hjertefrekvens (9). Studiene er ikke optimalt designet. Det var få pasienter totalt sett, det var særlig få som hadde så lave konsentrasjoner som de nye anbefalingene tilsier, og det ble ikke rapportert data på harde endepunkter $(8,9)$.

I preparatomtalen til det eneste digitoksinpreparatet som markedsføres i Norge, ble optimal plasmakonsentrasjon angitt til 20-33 nmol/1 helt fram til mars 2009 (10). Ved vårt laboratorium og de fleste andre norske laboratorier ble referanseområdene redusert fra $15-33 \mathrm{nmol} / \mathrm{l}$ til $8-15 \mathrm{nmol} / \mathrm{l} \mathrm{i}$ november 2007.

Målet med denne studien er å se nærmere på endringer i angitt dosering og serumkonsentrasjoner av digitoksin over tid, ikke minst for å dokumentere i hvor stor grad anbefalingene fra 2007 har fått gjennomslag.

\section{Materiale og metode}

I niårsperioden 1.1. 2000-31.12. 2008 ble det utført i alt 13054 serumkonsentrasjonsmålinger av digitoksin ved vår avdeling. Resultatene fra disse analysene ble systematisert og sammenliknet kvartalsvis. Fra 1.9. 2005 endret vårt laboratorium analysemetode. Dette medførte at konsentrasjoner målt før denne datoen måtte oppjusteres etter en bestemt algoritme (i gjennomsnitt med ca. $7 \%$ ) for å kunne sammenliknes med kon-

\section{Hovedbudskap}

- I om lag to tredeler av alle analyserte prøver i 2008 lå serumkonsentrasjonen av digitoksin over revidert referanseområde

- Vedlikeholdsdosen til en pasient i alderen 70-80 år bør være $50 \mu g$ 4-5 dager per uke

- Vedlikeholdsdosen til en pasient over 80 år bør være $50 \mu \mathrm{g} 3-4$ dager per uke, ev. $25 \mu \mathrm{g}$ daglig

- Oppfølging med serumkonsentrasjonsanalyser av digitoksin er fortsatt svært viktig 
sentrasjoner målt etter denne datoen. For å få direkte sammenliknbare tall er derfor alle verdier målt før 1.9. 2005 oppjustert med i gjennomsnitt ca. $7 \%$ i denne studien.

Opplysninger om dosering ble hentet fra rekvisisjonene. For å kunne studere effekt av alder på digitoksinnivå og digitoksinmetabolisme måtte serumkonsentrasjonene justeres i forhold til de dosene pasientene hadde brukt. Dette ble gjort ved at de målte konsentrasjonene ble regnet om til den konsentrasjonen den samme pasienten ville ha hatt hvis vedkommende hadde brukt en dose på $50 \mu \mathrm{g} / \mathrm{d}$. Følgende formel ble brukt til dette: Beregnet konsentrasjon $=$ målt konsentrasjon $\cdot 50 \mu \mathrm{g} /$ gjennomsnittlig faktisk daglig dose i $\mu \mathrm{g}$.

Studien ble forelagt sykehusets personvernombud, som ikke hadde innvendinger.

\section{Resultater}

I perioden $2000-08$ varierte antall analyserte prøver av digitoksin mellom $1099 \mathrm{og}$ 1935 per år og med en generelt synkende tendens. Aldersfordelingen var stabil, med en medianalder som varierte mellom 80 og 84 år for de ulike kvartalene.

Mediankonsentrasjonen av digitoksin lå stabilt på ca. $25 \mathrm{nmol} / 1$ til og med 2006 (fig 1). Fra 2007 sank mediankonsentrasjonen gradvis og var $19 \mathrm{nmol} / 1$ ved utgangen av 2008. Verdiene for 25- og 75-persentilene viste en tilsvarende tendens (fig 1). Andelen prøver med konsentrasjoner over $33 \mathrm{nmol} / \mathrm{l}$, dvs. øvre grense i det gamle referanseområdet, varierte mellom $10 \%$ og $20 \%$ frem til utgangen av 2006. I de fire kvartalene i 2008, etter at øvre grense i referanseområdet var blitt redusert til $15 \mathrm{nmol} / \mathrm{l}$, var andelen prøver med konsentrasjoner over referanseområdet økt til henholdsvis $69,65,66$ og $67 \%$.

Den gjennomsnittlige angitte døgndosen sank fra $66 \mu \mathrm{g}$ i 2000 , via $63 \mu \mathrm{g}$ i $2001 \mathrm{og}$ 2002, $61 \mu \mathrm{g}$ i 2003 og 2004, $60 \mu \mathrm{g}$ i 2005 , $59 \mu \mathrm{g}$ i 2006 og $57 \mu \mathrm{g}$ i 2007 , til $56 \mu \mathrm{g}$ i 2008. Den dosekorrigerte serumkonsentrasjonen økte med alderen (fig 2), og personer over 85 år hadde nesten dobbelt så høye konsentrasjoner på en gitt dose som personer under 55 år. Det var særlig fra 65 års alder at denne effekten satte inn.

\section{Diskusjon}

Denne studiens styrke, men også dens svakhet, er at tallene bygger på spontant innsendte prøver for analyse av digitoksin. På den ene side reflekterer materialet hvordan serumkonsentrasjonene fordeler seg i en naturalistisk populasjon som det tas prøver av. På den annen side kan materialet være selektert $\mathrm{i}$ den forstand at det ikke nødvendigvis tas prøver av alle - $\mathrm{i}$ alle fall tas det ikke prøver av alle like ofte. Dermed vil resultatene ikke nødvendigvis være representative for totalpopulasjonen av pasienter som bruker digitoksin. Det kan for eksempel tenkes at det tas prøver oftere av dem som er eldst, dem som er sykest, eller dem som bruker de høyeste dosene. Dette vil føre til at konsentrasjonene i materialet blir høyere enn i totalpopulasjonen. Likevel er det rimelig å anta at en majoritet av prøvene er rene rutineprøver. Tall fra Reseptregisteret viser at $54 \%$ av alle som får resept på digitoksin er 80 år eller mer (11). Dette tyder på at medianalderen på 80-84 år i vårt materiale er representativ for totalpopulasjonen.

De nye norske anbefalingene om redusert referanseområde og nye doseringsrutiner ble publisert i 2007 (1-3). Tidsskriftet var først ute i midten av april (1), senere samme år ble anbefalingene omtalt i Norsk legemiddelhåndbok (2) og i Norsk Cardiologisk Selskaps tidsskrift Hjerteforum (3). I november
2007 ble referanseområdene redusert ved de norske laboratoriene. Vår studie viser at konsentrasjonene begynte å synke allerede i 1. kvartal 2007, altså før anbefalingene ble publisert. Dette kan skyldes at de kardiologiske og farmakologiske fagmiljøene allerede da hadde begynt å diskutere endringene. Etter november 2007 fortsatte fallet $\mathrm{i}$ konsentrasjonsnivåene. Det er likevel bemerkelsesverdig at mediankonsentrasjonen ett år senere fortsatt lå på $19 \mathrm{nmol} / \mathrm{l}, \mathrm{og}$ at to av tre prøver hadde konsentrasjoner over øvre grense i det nye referanseområdet.

Digitalisglykosider har et smalt terapeutisk område. Symptomer på intoksikasjon kan oppstå allerede ved digitoksinkonsen-

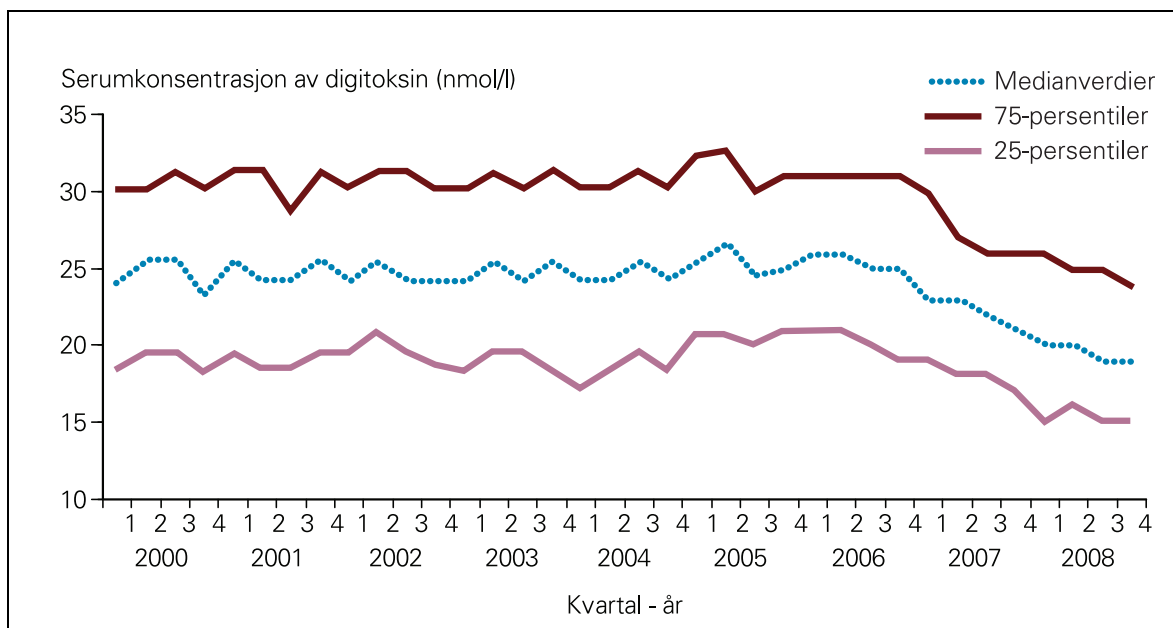

Figur 1 Målte serumkonsentrasjoner av digitoksin kvartal for kvartal i årene 2000-08. Konsentrasjonene er vist som medianverdier (stiplet lyseblå kurve), 25-persentiler (lyserød kurve) og 75-persentiler (mørkerød kurve). I alt er det inkludert data fra 13054 prøver



Figur 2 Mediankonsentrasjon av digitoksin i ulike aldersgrupper år for år i perioden 2000-08. Konsentrasjonene som er brukt i figuren, er beregnede konsentrasjoner som pasientene ville ha hatt hvis døgndosen hos alle hadde vært $50 \mu \mathrm{g}(0,05 \mathrm{mg})$. Kun prøver tatt i 2. kvartal hvert år er inkludert i analysen, i alt 3345 prøver 
trasjoner på 30-40 nmol/1 hos de eldste og sykeste pasientene. Symptomene kan være uspesifikke, slik som kvalme, anoreksi, diaré, tretthet, hodepine, kognitiv svikt og delirium, og potensielt alvorlige i form av hypokalemi og hjertearytmier. En fordel med det nye referanseområdet er at avstanden til toksisk nivå blir større, og at bivirkningsforekomsten trolig vil avta. Til tross for dette er oppfølging med serumkonsentrasjonsanalyser like viktig som før. Dette skyldes ikke minst at nedsatt ledningsevne i AV-knuten vil kunne oppstå allerede ved relativt lave konsentrasjoner.

Som ventet hadde de eldste pasientene også de høyeste dosekorrigerte serumkonsentrasjonene. Hvis man tar utgangspunkt i de påviste mediankonsentrasjonene, vil personer over 75 år som behandles med en dose på $50 \mu \mathrm{g} / \mathrm{d}$, få en konsentrasjon på 20-25 nmol/1, altså godt over øvre grenseverdi i det nye referanseområdet. Pasienter mellom 65 og 75 år som behandles med den samme dosen, vil få konsentrasjoner i størrelsesorden $15-20 \mathrm{nmol} / \mathrm{l}$, det vil si rundt eller noe over øvre grense i det nye referanseområdet. Det har vært foreslått at vanlig vedlikeholdsdose nå bør være $50 \mu \mathrm{g}(0,05 \mathrm{mg})$ daglig til alle, uavhengig av alder (1). Andre angir 30-50 $\mu \mathrm{g}$ daglig, eventuelt med 1-2 doseringsfrie dager i uken $(2,3)$. Siden digitoksin har en halveringstid på ca. en uke, vil et inntak som innbefatter noen tablettfrie dager per uke, likevel gi en jevn serumkonsentrasjon. Våre data tyder på at hos pasienter mellom $70 \mathrm{og}$ 80 år bør vedlikeholdsdosen i utgangspunktet være $50 \mu \mathrm{g} 4-5$ dager per uke, og hos pasienter over 80 år $50 \mu \mathrm{g} 3-4$ dager per uke, eventuelt en halv tablett $(25 \mu \mathrm{g})$ daglig. I den godkjente preparatomtalen for digitoksin angis fortsatt $0,05-0,1 \mathrm{mg}(50-100 \mu \mathrm{g})$ daglig (10). Dette er utvilsomt for høyt, fremfor alt med tanke på at majoriteten av norske pasienter som bruker digitoksin, er over 80 år.

Denne gjennomgangen viser at enkeltstudier, selv om de er basert på store pasientgrupper, ikke får gjennomslag uten videre. Den første studien ble publisert allerede $i$ 2003 (4). Det er ikke overraskende at travle leger ikke har tid og mulighet til å sette seg inn i fersk forskningslitteratur på alle områder, særlig ikke når det gjelder et legemiddel som brukes i stadig mindre grad. Men selv om salget gradvis synker, skrives det fortsatt ut digitoksin til mer enn 25000 pasienter hvert år (11).

For å få implementert resultater fra nye konsentrasjon-effekt-studier i klinisk praksis er det viktig med engasjerte pådrivere. De klinisk farmakologiske laboratoriene har en sentral rolle her, i samarbeid med relevante kliniske spesialiteter. Nedgangen i median serumkonsentrasjon har vært 19\% i løpet av 2007 og 2008. Dette tyder på at informasjonen har nådd frem til mange. Likevel har fortsatt to av tre prøver konsentrasjoner over det nye referanseområdet. Gammel forskrivningsvane spiller trolig en rolle i så måte, men det kan også være en medvirkende faktor at doseanbefalingene i preparatomtalen for digitoksin fortsatt er de samme som før 2007 (10). For lettere å kunne tilpasse doseringen av digitoksin til det nye anbefalte konsentrasjonsområdet er det ønskelig at det lanseres tabletter med styrke $25 \mu \mathrm{g}$.

\section{Oppgitte interessekonflikter: Ingen}

Litteratur

1. Madsen S, Holene E. Lavere digitalisdosering ved hjertesvikt. Tidsskr Nor Lægeforen 2007; 127: 1053-4.

2. Osnes J-B, Aass H. Hjerteglykosider. I: Norsk legemiddelhåndbok for helsepersonell 2007. Oslo: Foreningen for utgivelse av Norsk legemiddelhåndbok, 2007: 1015-8.

3. Skomedal S, Osnes J-B, Norsk Cardiologisk Selskaps arbeidsgruppe for hjertesvikt. Endring av anbefalt terapeutisk serumkonsentrasjonsområde for digoksin og digitoksin. Hjerteforum 2007; 20, nr. 4: 27-31.

4. Brørs 0. Legemiddelanalyser og rusmiddelanalyser. I: Norsk legemiddelhåndbok for helsepersonell 2004. Oslo: Foreningen for utgivelse av Norsk legemiddelhåndbok, 2004: 1601-8.

5. The Digitalis Investigation Group. The effect of digoxin in mortality and morbidity in patients with heart failure. N Engl J Med 1997; 336: 525-33.

6. Rathore SS, Curtis JP, Wang Y et al. Association of serum digoxin concentration and outcomes in patients with heart failure. JAMA 2003; 289: 871-8.

7. Ahmed A, Rich MW, Love TE et al. Digoxin and reduction in mortality and hospitalization in heart failure: a comprehensive post hoc analysis of the DIG trial. Eur Heart J 2006: 27: 178-86.

8. Chamberlain DA, White RJ, Howard MR et al. Plasma digoxin concentrations in patients with atrial fibrillation. BMJ 1970; 3: 429-32.

9. Goldman S, Probst P, Selzer A et al. Inefficacy of «therapeutic» serum levels of digoxin in controlling the ventricular rate in atrial fibrillation. Am J Cardiol 1975; 35: 651-5.

10. Statens legemiddelverk. Preparatomtale, Digitoxin. www.legemiddelverket.no/custom/ Preparatsok/prepSearch__ 80333.aspx? SearchID=bbf8edc7-817 $\overline{d-48} \mathrm{e} 8-\mathrm{b} 7 \mathrm{e} 7-$ d341aa39b6c1 (17.9.2009).

11. Statistikk fra Reseptregisteret. Digitoksin. www.reseptregisteret.no/Prevalens/aspx [17.9.2009].

Manuskriptet ble mottatt 28.9. 2009 og godkjent 15.4 2010. Medisinsk redaktør Petter Gjersvik. 